\title{
Results from the Italian participation in the International Co-operative Programme on Assessment and Monitoring of Acidification of Rivers and Lakes (ICP Waters)
}

\author{
Rosario MOSELLO*, Aldo MARCHETTO, Maria C. BRIZZIO, Michela ROGORA and Gabriele A. TARTARI \\ CNR Istituto Italiano di Idrobiologia, L.go V. Tonolli 50, 28922 Verbania Pallanza, Italy \\ *e-mail corresponding author: r.mosello@iii.to.cnr.it
}

\begin{abstract}
This paper describes the research activity carried out by the Istituto Italiano di Idrobiologia of the CNR, on behalf of the Ministero dell'Ambiente, Servizio Inquinamento Atmosferico e Acustico, in the context of the Italian participation in the International Cooperative Programme on Assessment and Monitoring of Acidification of Rivers and Lakes (ICP Waters). Atmospheric deposition chemistry shows that nitrate increased and sulphate decreased in the 70's and 80's, while acidity started to decrease in the early 90 's. The studied rivers and lakes show variations in sulphate and nitrate in agreement with those of atmospheric deposition. Alkalinity is mainly determined by watershed geo-lithology and is always present in the studied lakes and streams; the lowest values of 0-10 $\mu$ eq $l^{-1}$ are measured in the high altitude Lake Paione Superiore, which however shows an increasing trend of alkalinity and $\mathrm{pH}$.
\end{abstract}

Key words: North Italy, acidification, nitrate, surface water, trend

\section{INTRODUCTION}

In 1995 the Istituto Italiano di Idrobiologia of the CNR was appointed by the Ministero dell'Ambiente, Servizio Inquinamento Atmosferico e Acustico, to coordinate the Italian participation in the International Cooperative Programme (ICP) "Assessment and monitoring of acidification of rivers and lakes", which forms part of the scientific research endorsed by the United Nations - Economic Council of Europe. The ICP-Waters programme was established under the executive body of the Convention on Long-Range Transboundary Air Pollution (LRTAP) in July 1985 and is one of the five ICP's which consider the effects of atmospheric pollutant deposition on surface water, forests, materials, crops and ecosystems (Lükewille et al. 1997).

The objective of the programme is to establish an international network of surface water monitoring sites and promote international harmonisation of monitoring practices, for example through definition of sampling protocols and inter-laboratory quality assurance tests. The main programme aims are:

- to establish the degree and geographical extent of surface water acidification;

- to collect information about dose-response relationship between water chemistry and biota under different conditions;

- to define long-term trends in water chemistry by using sites with data of more than five years, with particular attention to acidification processes and nitrogen deposition.

The Istituto Italiano di Idrobiologia was able to participate in the programme thanks to the great amount of data collected over the last two decades on several lakes and rivers located in the northern part of Italy and considered in various research projects, still in progress. In particular, studies on tributaries of Lake Maggiore started in 1973, in the context of research on eutrophication in the lake (de Bernardi et al. 1996), while measures on tributaries of Lake Orta began in 1984, as part of the recovery plan for this lake, which was severely polluted by industrial sources (Calderoni et al. 1993, 1994). Research on Lake Mergozzo was also mainly aimed at the study of eutrophication and trophic relationships (Calderoni et al. 1978; de Bernardi et al. 1996). Finally, studies on atmospheric deposition started in the 1980's, as part of research programmes on acidification of surface water, concentrating especially on alpine lakes (Mosello et al. 1993a; Marchetto et al. 1994).

\section{STUDY AREA, SAMPLING AND METHODS}

Rivers and lakes considered were selected on the basis of the following criteria:

- areas affected by high deposition of atmospheric pollutants;

- minimal direct anthropogenic disturbance;

- availability of information on the main characteristics of the watershed;

- previously collected chemical and biological data, with protocols close to those adopted in the programme.

The rivers and lakes chosen are all located in the Lake Maggiore watershed (Fig. 1); their main characteristics are reported in table 1.

Lakes Paione Superiore and Inferiore are high mountain lakes, situated in the Bognanco Valley (Os- 


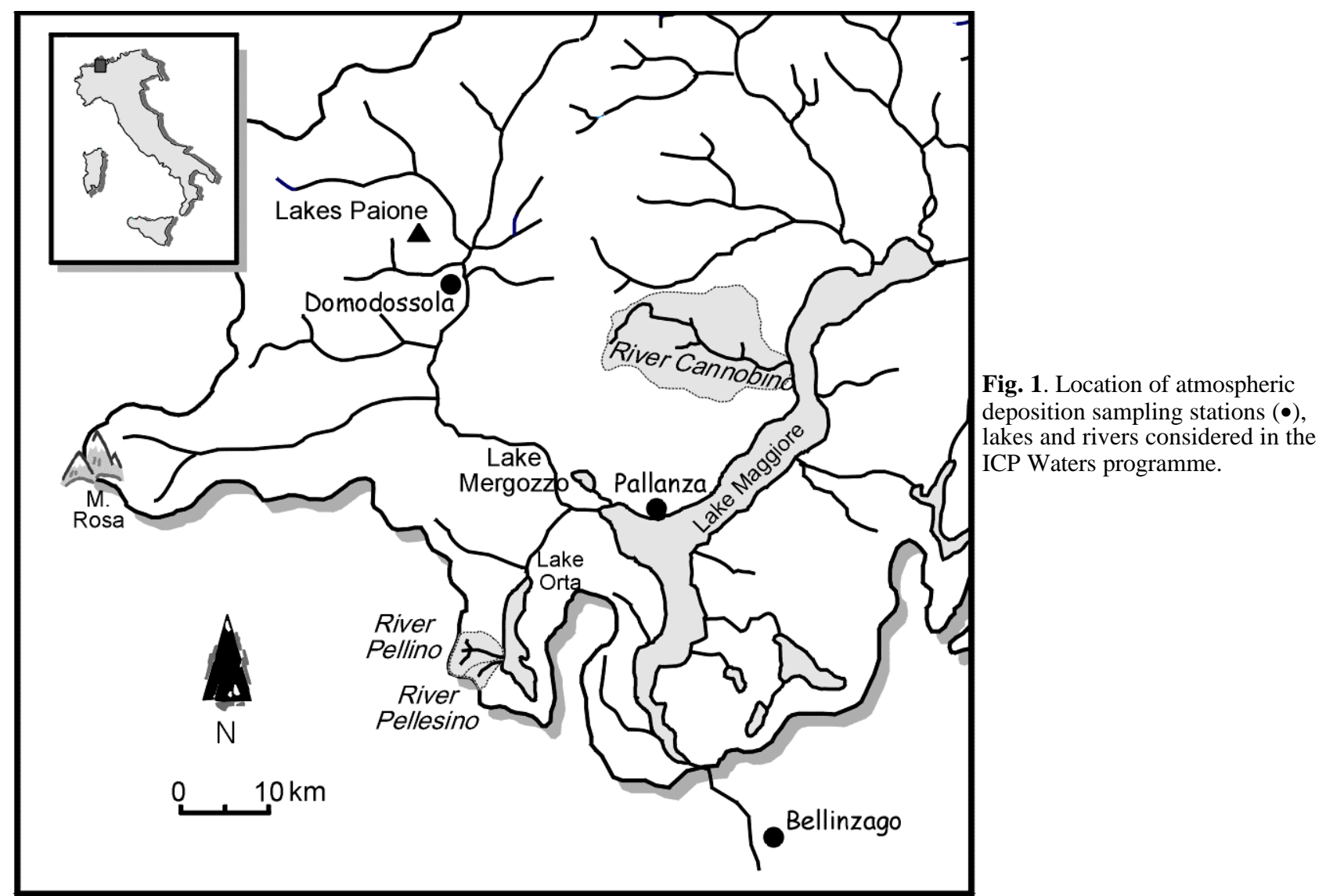

Tab. 1. Some selected geographical and morphometric characteristics of the lakes and rivers considered.

\begin{tabular}{|c|c|c|c|c|c|c|c|}
\hline & & $\begin{array}{c}\text { Lake Paione } \\
\text { Superiore }\end{array}$ & $\begin{array}{l}\text { Lake Paione } \\
\text { Inferiore }\end{array}$ & $\begin{array}{c}\text { Lake } \\
\text { Mergozzo }\end{array}$ & $\begin{array}{l}\text { River } \\
\text { Pellino }\end{array}$ & $\begin{array}{c}\text { River } \\
\text { Pellesino }\end{array}$ & $\begin{array}{c}\text { River } \\
\text { Cannobino }\end{array}$ \\
\hline Altitude & m a.s.l. & 2269 & 2002 & 194 & 290 & 290 & 193 \\
\hline Catchment area & $\mathrm{km}^{2}$ & 0.50 & 1.26 & 10.43 & 17.5 & 3.4 & 110.4 \\
\hline Lake area & $\mathrm{km}^{2}$ & 0.0086 & 0.0068 & 1.83 & - & - & - \\
\hline Mean depth & $\mathrm{m}$ & 5.1 & 7.4 & 45.4 & - & - & - \\
\hline Max depth & $\mathrm{m}$ & 11.5 & 13.5 & 73 & - & - & - \\
\hline Average precipitation & $\mathrm{mm} \mathrm{y}^{-1}$ & 1400 & 1450 & 1885 & $2000-2100$ & $2000-2200$ & $1600-2700$ \\
\hline Renewal time & $\mathrm{d}$ & 33 & 23 & 1716 & - & - & - \\
\hline Average catchment runoff & $1 \mathrm{~s}^{-1} \mathrm{~km}^{-2}$ & 44 & 46 & 42 & 53 & 54 & 46 \\
\hline Yearly average flow & $\mathrm{m}^{3} \mathrm{~s}^{-1}$ & - & - & - & 0.92 & 0.19 & 5.04 \\
\hline
\end{tabular}

sola Valley, Central Alps) at 2269 and 2002 m a.s.l. respectively. They are located above the timberline, in an area not affected by local disturbances or direct anthropogenic sources of pollutants. The only vegetation in their catchments is alpine meadow, limited to restricted areas; soils are absent or very thin and the geo-lithological composition is mainly acidic. As a result they are very sensitive to acidification (Mosello et al. 1999).

The other sites are located in the subalpine area: Lake Mergozzo is very close to Lake Maggiore, at 198 $\mathrm{m}$ a.s.l.; the Rivers Pellino and Pellesino are tributaries of Lake Orta on the left shore of the lake near the village of Pella, while the River Cannobino, farther north than the others, is a tributary of Lake Maggiore and enters the lake near the town of Cannobio. The subalpine areas are thinly populated and do not include any intensive industrial, stock-rearing or agricultural activity.

The watershed of Lake Mergozzo is small compared to the lake surface (Tab. 1); the north-eastern part of the basin is characterised by metamorphic rocks, while the south-western side is formed mainly of granites. About $69 \%$ of the catchment surface is covered with deciduous forest (Calderoni et al. 1978).

The tributaries of Lake Orta have small watersheds (Tab. 1) compared to that of the River Cannobino, which is also longer (27 km as opposed to 11.7 and 7.4 $\mathrm{km}$ of Pellino and Pellesino respectively). The land cover is quite similar in the catchments of the rivers Pellino and Pellesino and comprises mainly mixed deciduous forest, representing about $80 \%$ of the watershed 
area. From a geological point of view, their catchments are made up only of granitic and granodioritic rocks. The River Cannobino watershed is subjected to greater anthropogenic pressure near the villages along the shoreline of Lake Maggiore; vegetation occupies more of the watershed as the altitude rises, with coniferous forest covering about $43 \%$ of the total surface. Gneisses, micaschists and paragneiss are very common but in the upper part of the watershed basic rocks are also present (Boggero et al. 1996).

Although not included in the ICP Waters programme, the chemistry of atmospheric deposition affecting the subalpine area has been considered through data collected in seven sampling stations (Mosello et al. 1993b). To evaluate the correlation between surface water trends and atmospheric deposition, in this paper we consider three sampling sites, listed in table 2. Pallanza and Domodossola are small towns, of about 35,000 and 20,000 inhabitants respectively; the former is located on the shore of Lake Maggiore, at about 210 $\mathrm{m}$ a.s.l., the latter is at the end of the Ossola Valley, at $270 \mathrm{~m}$ a.s.l. (Fig. 1). The sampling site of Bellinzago is situated in a Regional Nature Reserve not far from industrial areas, and $3 \mathrm{~km}$ North-North West of the thermoelectric power generator of Turbigo (1300 Mwatt). Pallanza was the first station to be operative: bulk samples were collected in 1975-76 and again from 1980. From 1984, wet samples were also collected at Pallanza, in order to evaluate the comparability of different samplers: the differences were small as regards major ion concentrations, and negligible in the case of $\mathrm{pH}$ values (Mosello et al. 1988, 1993b). Sampling frequency was weekly in all the stations, with the exception of Pallanza, where single events were sampled in 1975-76 and then from 1988. Monthly values were calculated as volume weighted mean concentrations.

Tab. 2. Some selected geographical characteristics of the atmospheric deposition sampling stations.

\begin{tabular}{lrcccc}
\hline Sampling station & & Period & $\begin{array}{c}\text { Alt. } \\
\text { (m a.s.1.) }\end{array}$ & Latitude & Longitude \\
\hline Pallanza & bulk & $1975-98$ & 208 & $45^{\circ} 55^{\prime}$ & $8^{\circ} 34^{\prime}$ \\
& wet & $1984-98$ & & & \\
Domodossola & wet & $1986-98$ & 270 & $46^{\circ} 06^{\prime}$ & $8^{\circ} 12^{\prime}$ \\
Bellinzago & wet & $1989-98$ & 190 & $45^{\circ} 35^{\prime}$ & $8^{\circ} 40^{\prime}$ \\
\hline
\end{tabular}

Variables considered were: $\mathrm{pH}$, conductivity at 20 ${ }^{\circ} \mathrm{C}$, alkalinity (acidimetric titration), sulphate (turbidimetry), nitrate (spectrophotometric, salicylate), chloride (spectrophotometric, tallium and, since 1982, ion selective electrode), calcium, magnesium, sodium and potassium (atomic absorption), ammonium, reactive silica and reactive and total phosphorus by spectrophotometry (indophenol-blue and ammonium molibdate with ascorbic acid, respectively). A major change was the introduction of ion chromatography in 1984 for anions and in 1991 for cations. To evaluate the compara- bility of the results, paired analyses were carried out on 410 samples representing the whole range of concentrations. No systematic differences emerged for nitrate, while sulphate and chloride may have been overestimated with the older techniques, particularly at lower concentrations. Differences were also found for magnesium, sodium and potassium, which were slightly overestimated by atomic absorption. (Della Lucia et al. 1996; Tartari \& Mosello 1997).

The results of the chemical analyses were validated taking into account the difference between the sum of anion and cation concentrations and the difference between measured and calculated conductivity. Details of the analytical methods and quality controls are reported in Tartari \& Mosello (1997).

The statistical method used for trend evaluation is the non-parametric seasonal Kendall test (Hirsch et al. 1982). To study seasonal variations we used the nonparametric Kruskall-Wallis test (Lükewille et al. 1997).

\section{RESULTS}

\subsection{Atmospheric deposition}

The deposition collected in the three sampling stations is characterised by high acidity: the 1998 values of $\mathrm{pH}$ corresponding to their volume-weighted hydrogen ion concentration are between 4.6 and 4.7. Sulphate and nitrate are the most important anions, while ammonium plays an important role among cations together with calcium and hydrogen ion (Tab. 3).

There are significant seasonal differences in amounts of precipitation, with probability level $(p)$ $<0.001$ (Tab. 4). The chemical variables all show significant seasonality in the sampling site of Pallanza, with the exception of sodium and potassium in the case of bulk samples, and chloride for wet samples. Apart from those at Domodossola, all the chemical variables have a significant seasonal pattern. Seasonality is less marked in the station of Bellinzago, where the only marked variations $(p<0.001)$ are those of $\mathrm{pH}$ and hydrogen ion.

As to the long term trends (Tab. 4), nitrogen compounds have decreased significantly only in the case of Bellinzago. Acidity is decreasing in all the stations, as the significant increase in $\mathrm{pH}$ values $(p<0.001)$ shows. The trend of basic cations, in particular calcium and magnesium, is towards a decrease, with high significance at Pallanza and Domodossola.

The main trends for the period 1975-98 at Pallanza are illustrated in figure 2 as a twelve-point running average on monthly concentrations. Sulphate values show a marked decrease, with a high level of significance ( $p$ $<0.001$, Tab. 4), from about $120-130 \mu \mathrm{eq} 1^{-1}$ in 1980-81 to $50-60 \mu \mathrm{eq} 1^{-1}$ in the last three years. As a consequence, $\mathrm{pH}$ has increased from 4.3-4.4 to about 4.7. Nitrate concentrations in the same site have increased slightly $(p<0.05)$, while the variation in ammonium is 
Tab. 3. Volume weighted mean values (1998) of the main chemical variables in the atmospheric depositions, lakes and rivers considered.

\begin{tabular}{|c|c|c|c|c|c|c|c|c|c|c|c|}
\hline & & $\begin{array}{l}\text { Pallanza } \\
\text { bulk }\end{array}$ & $\begin{array}{l}\text { Pallanza } \\
\text { wet }\end{array}$ & $\begin{array}{c}\text { Domodossola } \\
\text { wet }\end{array}$ & $\begin{array}{c}\text { Bellinzago } \\
\text { wet }\end{array}$ & $\begin{array}{l}\text { L. Paione } \\
\text { Superiore }\end{array}$ & $\begin{array}{l}\text { L. Paione } \\
\text { Inferiore }\end{array}$ & $\begin{array}{c}\text { Lake } \\
\text { Mergozzo }\end{array}$ & $\begin{array}{l}\text { River } \\
\text { Pellino }\end{array}$ & $\begin{array}{c}\text { River } \\
\text { Pellesino }\end{array}$ & $\begin{array}{c}\text { River } \\
\text { Cannobino }\end{array}$ \\
\hline pH & & 4.68 & 4.60 & 4.69 & 4.68 & 5.78 & 6.28 & 6.84 & 7.23 & 7.18 & 7.28 \\
\hline Conductivity & $\mu \mathrm{S} \mathrm{cm}^{-1} 20^{\circ} \mathrm{C}$ & 21.1 & 22.4 & 15.4 & 21.1 & 9.6 & 12.4 & 50.9 & 49.0 & 42.9 & 41.0 \\
\hline $\mathrm{H}^{+}$ & $\mu e q 1^{-1}$ & 21 & 25 & 20 & 21 & 2 & 1 & 0 & 0 & 0 & 0 \\
\hline $\mathrm{NH}_{4}^{+}$ & $\mu e q 1^{-1}$ & 59 & 54 & 30 & 65 & 3 & 1 & 0 & 1 & 2 & 1 \\
\hline $\mathrm{Ca}^{++}$ & $\mu e q 1^{-1}$ & 22 & 15 & 10 & 15 & 43 & 69 & 277 & 223 & 172 & 200 \\
\hline $\mathrm{Mg}^{++}$ & $\mu e q 1^{-1}$ & 6 & 3 & 2 & 5 & 8 & 11 & 114 & 93 & 63 & 115 \\
\hline $\mathrm{Na}^{+}$ & $\mu e q 1^{-1}$ & 11 & 9 & 4 & 12 & 10 & 15 & 86 & 146 & 157 & 72 \\
\hline $\mathrm{K}^{+}$ & $\mu e q 1^{-1}$ & 4 & 3 & 2 & 5 & 7 & 8 & 23 & 12 & 12 & 17 \\
\hline Alkalinity & $\mu e q 1^{-1}$ & 4 & 2 & 1 & 6 & 9 & 32 & 230 & 196 & 160 & 216 \\
\hline $\mathrm{Cl}^{-}$ & $\mu e q 1^{-1}$ & 10 & 8 & 4 & 11 & 4 & 5 & 37 & 55 & 62 & 24 \\
\hline $\mathrm{SO}_{4}=$ & $\mu e q 1^{-1}$ & 52 & 49 & 28 & 49 & 36 & 44 & 181 & 93 & 69 & 112 \\
\hline $\mathrm{NO}_{3}^{-}$ & $\mu e q 1^{-1}$ & 50 & 45 & 31 & 49 & 27 & 29 & 45 & 121 & 111 & 46 \\
\hline Reactive P & $\mu \mathrm{g} \mathrm{P} 1^{-1}$ & 11 & 7 & 3 & 9 & 1 & 1 & 1 & 8 & 20 & 4 \\
\hline Total P & $\mu \mathrm{g} \mathrm{P} 1^{-1}$ & - & - & - & - & 3 & 2 & 5 & 12 & 30 & 6 \\
\hline Total N & $\mathrm{mg} \mathrm{N}^{-1}$ & - & - & - & - & - & - & 0.77 & 1.89 & 1.82 & 0.76 \\
\hline Reactive Si & $\mathrm{mg} \mathrm{Si} \mathrm{l}^{-1}$ & - & - & - & - & 0.49 & 0.86 & 1.59 & 6.52 & 6.95 & 3.76 \\
\hline$\sum$ Anions & $\mu e q 1^{-1}$ & 116 & 104 & 64 & 115 & 76 & 110 & 493 & 466 & 401 & 399 \\
\hline$\Sigma$ Cations & $\mu e q 1^{-1}$ & 123 & 109 & 69 & 123 & 74 & 104 & 501 & 474 & 407 & 406 \\
\hline$\Sigma$ Ions & $\mu e q 1^{-1}$ & 239 & 213 & 134 & 238 & 150 & 214 & 994 & 940 & 808 & 804 \\
\hline
\end{tabular}

Tab. 4. Significant seasonal differences and trends of amount and chemistry of atmospheric depositions. KW: Kruskall-Wallis test; KT: Kendall test. Probability level: *<0.05; **<0.01; ***<0.001. +: increasing trend; -: decreasing trend.

\begin{tabular}{|c|c|c|c|c|c|c|c|c|}
\hline & \multicolumn{2}{|c|}{$\begin{array}{c}\text { Pallanza bulk } \\
\text { 1975-98 }\end{array}$} & \multicolumn{2}{|c|}{$\begin{array}{c}\text { Pallanza wet } \\
1984-98\end{array}$} & \multicolumn{2}{|c|}{$\begin{array}{c}\text { Domodossola wet } \\
1986-98\end{array}$} & \multicolumn{2}{|c|}{$\begin{array}{c}\text { Bellinzago wet } \\
1989-98\end{array}$} \\
\hline & $\begin{array}{c}\text { Seasonality } \\
\text { (KW) }\end{array}$ & $\begin{array}{l}\text { Trend } \\
(\mathrm{KT})\end{array}$ & $\begin{array}{l}\text { Seasonality } \\
(\mathrm{KW})\end{array}$ & $\begin{array}{l}\text { Trend } \\
(\mathrm{KT})\end{array}$ & $\begin{array}{l}\text { Seasonality } \\
(\mathrm{KW})\end{array}$ & $\begin{array}{l}\text { Trend } \\
(\mathrm{KT})\end{array}$ & $\begin{array}{l}\text { Seasonality } \\
\text { (KW) }\end{array}$ & $\begin{array}{l}\text { Trend } \\
(\mathrm{KT})\end{array}$ \\
\hline Amount & $* * *$ & & $* * *$ & & $* *$ & & $* * *$ & \\
\hline $\mathrm{pH}$ & $* * *$ & $* * *(+)$ & $* * *$ & $* * *(+)$ & & $* * *(+)$ & $* * *$ & $* * *(+)$ \\
\hline Hydrogen ion & $* * * *$ & $* * *(-)$ & $* *$ & $* * *(-)$ & & $* * *(-)$ & $* * *$ & $* * *(-)$ \\
\hline Conductivity & $* *$ & $* * *(-)$ & $*$ & $* * *(-)$ & $* * *$ & $* * *(-)$ & $* *$ & $* * *(-)$ \\
\hline Calcium & $* * *$ & $* * *(-)$ & $* * *$ & $*(-)$ & $* * *$ & $* * *(-)$ & $* *$ & $*(-)$ \\
\hline Magnesium & $* *$ & $* * *(-)$ & $* *$ & $* *(-)$ & $* * *$ & $* * *(-)$ & ** & $* * *(-)$ \\
\hline Sodium & & $*(-)$ & $*$ & & $* * *$ & $*(-)$ & & \\
\hline Potassium & & $*(-)$ & ** & & $* * *$ & & & $* * *(-)$ \\
\hline Ammonium & $* * *$ & & $* * *$ & & $* * *$ & $*(-)$ & * & $* * *(-)$ \\
\hline Sulphate & $* * *$ & $* * *(-)$ & $* * *$ & $* * *(-)$ & $* * *$ & $* * *(-)$ & * & $* * *(-)$ \\
\hline Nitrate & ** & $*(+)$ & ** & & $* * *$ & & $*$ & $* * *(-)$ \\
\hline Chloride & * & $* * *(-)$ & & $* *(-)$ & $* *$ & $* * *(-)$ & $* *$ & $*(-)$ \\
\hline Phosphate & * & $* * *(+)$ & $*$ & $* * *(+)$ & & $* * *(+)$ & & $* *(+)$ \\
\hline
\end{tabular}

not significant, with the mean values varying around 60$70 \mu$ eq $1^{-1}$.

\subsection{Lakes}

Lake Mergozzo is one of the few subalpine lakes in Italy which is oligotrophic, owing to low anthropogenic disturbance (de Bernardi et al. 1996; Calderoni et al. 1978). The mean alkalinity value of its water, about 220 $\mu$ eq $1^{-1}$ (Tab. 3), makes it slightly sensitive to acidification; atmospheric input plays an important role on its water chemistry because of the low ratio of catchment surface to lake area (about 5). Figure 3 shows the longterm trends of alkalinity, sum of basic cations, sulphate and nitrate, measured at water mixing, in the period 1968-98: in 1970-78 there was a marked decrease in alkalinity, from $220 \mu \mathrm{eq} \mathrm{l}^{-1}$ to about $180 \mu \mathrm{eq} \mathrm{l}^{-1}$; it then began to increase, reaching values of $220-230 \mu \mathrm{eq} 1^{-1}$ in recent years. The basic cations $\left(\mathrm{Ca}^{++}, \mathrm{Mg}^{++}, \mathrm{Na}^{+}, \mathrm{K}^{+}\right)$ passed from about $520 \mu \mathrm{eq} \mathrm{l}^{-1}$ in the period 1982-92 to
490-500 $\mu$ eq $1^{-1}$ in 1997-99. Sulphate has decreased markedly since 1984, while nitrate has increased, in good agreement with deposition trends.

Because of the geo-lithological composition of its catchment and the low ratio of watershed area to lake surface, Lake Paione Superiore is extremely sensitive to acidification processes. Its alkalinity values are close to 0 and $\mathrm{pH}$ ranges between 5.5 and 6.3 (Tab. 3). Lake Paione Inferiore has a catchment which contains small amounts of more soluble minerals, such as micaschists, and thus shows higher values of alkalinity (26-38 $\mu$ eq $1^{-1}$ ) and $\mathrm{pH}(6.1-6.5)$. The ionic content of both lakes is very low (150 and $214 \mu \mathrm{eq} \mathrm{l}^{-1}$ respectively) and is mainly composed of sulphate, nitrate and calcium (Mosello et al. 1999). The long term trends of $\mathrm{pH}$, alkalinity, sulphate and nitrate are shown in figure 4 . In the considered period (1984-98) there was a marked increase in $\mathrm{pH}$ and alkalinity values, particularly evident in the case of Lake Paione Superiore, where $\mathrm{pH}$ has increased from 

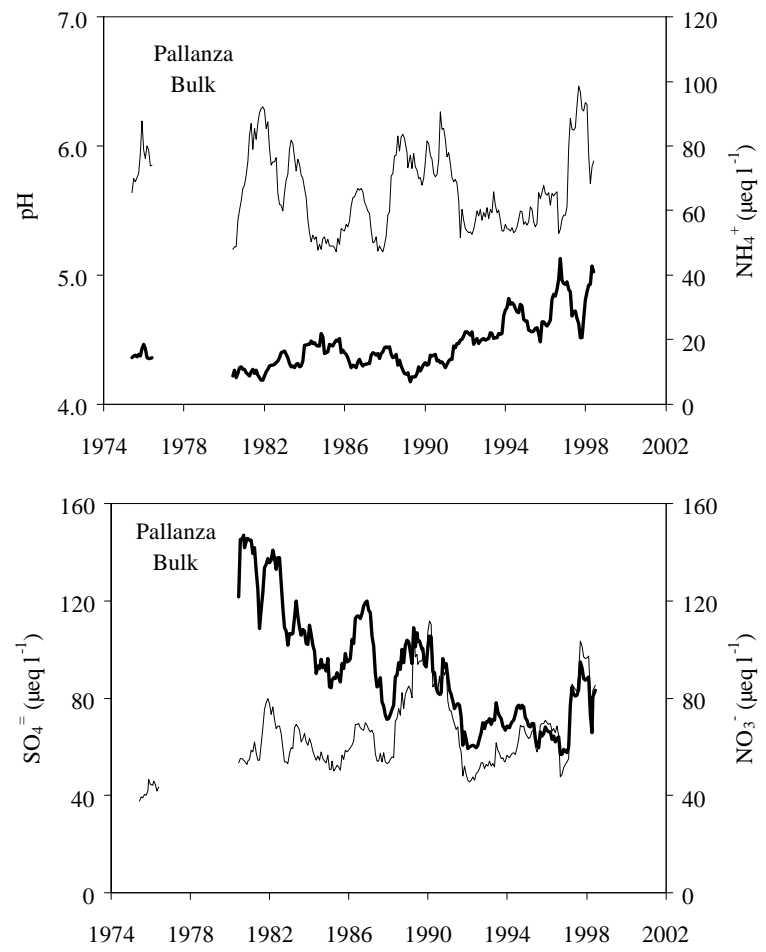

Fig. 2. Upper panel: trend (1975-98) of $\mathrm{pH}$ (thick line) and $\mathrm{NH}_{4}{ }^{+}$(thin line). Lower panel: trend of $\mathrm{SO}_{4}{ }^{-}$(thick line) and $\mathrm{NO}_{3}{ }^{-}$(thin line) as twelve point running average on monthly concentrations in the atmospheric deposition sampling station of Pallanza.

5.3-5.8 before 1992 to the present values of around 6.0. In Lake Paione Inferiore, $\mathrm{pH}$ has always been above 6.0, and in recent years has increased to 6.4. There is a similar upward trend for alkalinity which emerges clearly for Lake Paione Superiore, in spite of very marked seasonal fluctuations. Sulphate and nitrate do not present such clear variations, though sulphate concentrations appear to be decreasing slightly compared to the values of the period 1988-92.

\subsection{Rivers}

The three rivers considered are characterised by low solute concentrations (conductivity between 41 and 49 $\mu \mathrm{S} \mathrm{cm}{ }^{-1}$ ) and by the prevalence of calcium among cations (170-220 $\mu \mathrm{eq} \mathrm{l}^{-1}$ ). Their waters have a good neutralising capacity, as is shown by mean alkalinity values of $160-200 \mu$ eq $1^{-1}$, so extreme acidification events are unlikely. The main difference between them is the level of nitrate, which represent the main fraction of nitrogen compounds in these river waters. The mean concentrations are $110-120 \mu \mathrm{eq} 1^{-1}$ for the rivers Pellino and Pellesino and about $50 \mu \mathrm{eq} \mathrm{I}^{-1}$ for the River Cannobino (Tab. 3).

Seasonal variations of flow, temperature and chemistry are shown in table 5. All the solutes deriving from weathering processes $\left(\mathrm{Ca}^{++}, \mathrm{Mg}^{++}, \mathrm{Na}^{+}, \mathrm{K}^{+}, \mathrm{SO}_{4}{ }^{=}\right.$, alkalinity, silicate) show significant seasonality, less marked
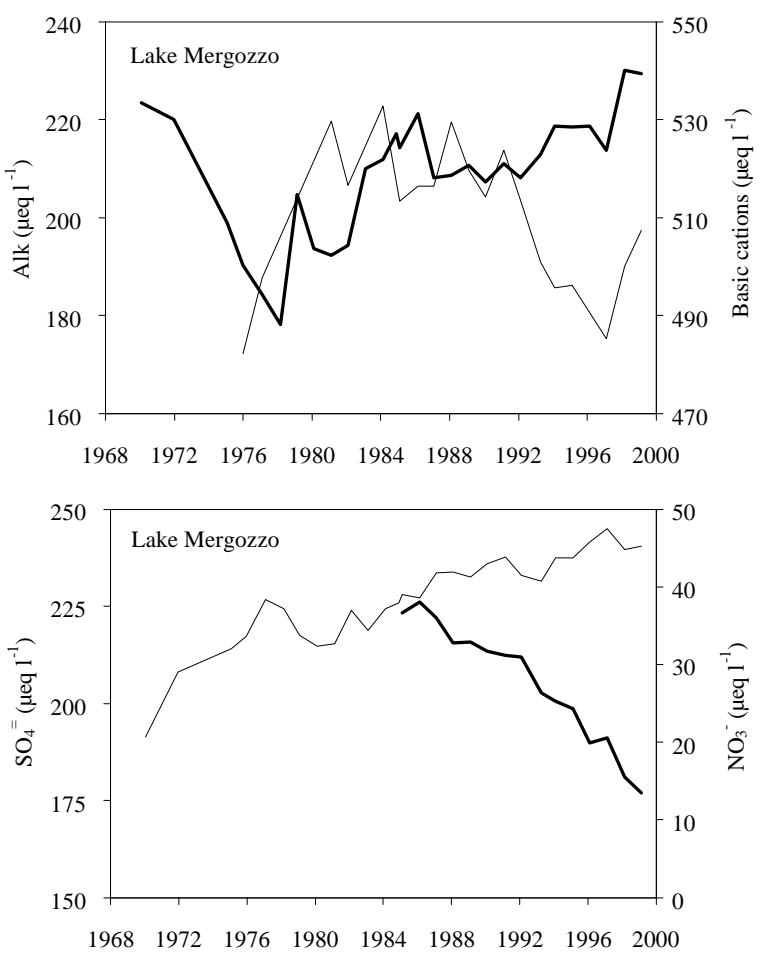

Fig. 3. Upper panel: trend of alkalinity (thick line) and sum of basic cations (thin line); lower panel, $\mathrm{SO}_{4}{ }^{2}$ (thick line) and $\mathrm{NO}_{3}{ }^{-}$(thin line) measured at water mixing in Lake Mergozzo.

in the case of the Pellino and the Pellesino which are characterised by smaller catchments and a more irregular flow. Seasonality is almost absent for nitrogen compounds $\left(\mathrm{NH}_{4}{ }^{+}, \mathrm{NO}_{3}{ }^{-}\right.$and total nitrogen) in all the rivers, while it is significant $(p<0.001)$ for reactive and total phosphorus only in the Pellino and the Pellesino.

As for the long term trends of the main variables, alkalinity values show no trend other than a slight increase in River Cannobino (Tab. 5), assuring the stability of the water chemistry towards acidification processes. However, the chemical characteristics of the river waters are dependent on those of atmospheric deposition, as is evident from the trend shown in figure 5 . The trend of nitrate is increasing $(p<0.001)$ in all the rivers, showing how the atmospheric input of this compound exceeds the uptake capacity of vegetation and soils (Boggero et al. 1996; Mosello et al. 1993c). Sulphate shows a significant decreasing trend in the rivers Pellino and Pellesino, while for the Cannobino this trend is less marked. An important aspect is also the sharply increasing trend of reactive silica ( $p<0.001$ for all the rivers considered).

\section{DISCUSSION AND CONCLUSIONS}

Previous studies carried out by the researchers of the Istituto Italiano di Idrobiologia showed how the northwestern part of Italy is affected by acid deposition (Mo- 
Tab. 5. Significant seasonal and long term trends for the rivers considered. KW: Kruskall-Wallis test; KT: Kendall test. Probability level: $*<0.05 ; * *<0.01 ; * * *<0.001 .+$ : increasing trend; -: decreasing trend.

\begin{tabular}{|c|c|c|c|c|c|c|}
\hline & \multicolumn{2}{|c|}{$\begin{array}{c}\text { River Pellino } \\
1984-98\end{array}$} & \multicolumn{2}{|c|}{$\begin{array}{c}\text { River Pellesino } \\
1986-98\end{array}$} & \multicolumn{2}{|c|}{$\begin{array}{c}\text { River Cannobino } \\
1978-98\end{array}$} \\
\hline & Seasonality (KW) & Trend (KT) & Seasonality (KW) & Trend (KT) & Seasonality (KW) & Trend (KT) \\
\hline Flow & $* * *$ & & $* * *$ & & & \\
\hline Temperature & $* * *$ & & $* * *$ & & $* * *$ & \\
\hline $\mathrm{pH}$ & $* * *$ & & $* * *$ & & $*$ & $* *(+)$ \\
\hline Conductivity & ** & $* * *(+)$ & $* * *$ & & ** & \\
\hline Alkalinity & $* * *$ & & $* * *$ & & *** & $*(+)$ \\
\hline Calcium & $*$ & $*(+)$ & $*$ & $* *(-)$ & ** & $* *(+)$ \\
\hline Magnesium & & $*(+)$ & $*$ & $* * *(-)$ & $* *$ & $*(+)$ \\
\hline Sodium & $*$ & $* * *(+)$ & $* *$ & $* * *(+)$ & $* *$ & $* * *(+)$ \\
\hline Potassium & $* * *$ & $*(+)$ & $*$ & & $* * *$ & \\
\hline Ammonium & & $* * *(+)$ & $*$ & $* * *(+)$ & & $* * *(-)$ \\
\hline Sulphate & & $* * *(-)$ & & $* * *(-)$ & $* * *$ & $*(-)$ \\
\hline Nitrate & & $* * *(+)$ & $*$ & $* * *(+)$ & & $* * *(+)$ \\
\hline Chloride & $*$ & $* * *(+)$ & $* *$ & $* * *(+)$ & $* * *$ & $* * *(+)$ \\
\hline Reactive phosphorus & $* * *$ & $* * *(+)$ & $* * *$ & $* * *(+)$ & & $* *(-)$ \\
\hline Total phosphorus & $* * *$ & $* *(-)$ & $* * *$ & $* * *(+)$ & & $* * *(-)$ \\
\hline Total nitrogen & & $* * *(+)$ & & $* * *(+)$ & & \\
\hline Reactive silica & $* *$ & $* * *(+)$ & $* * *$ & $* * *(+)$ & $* * *$ & $* * *(+)$ \\
\hline
\end{tabular}
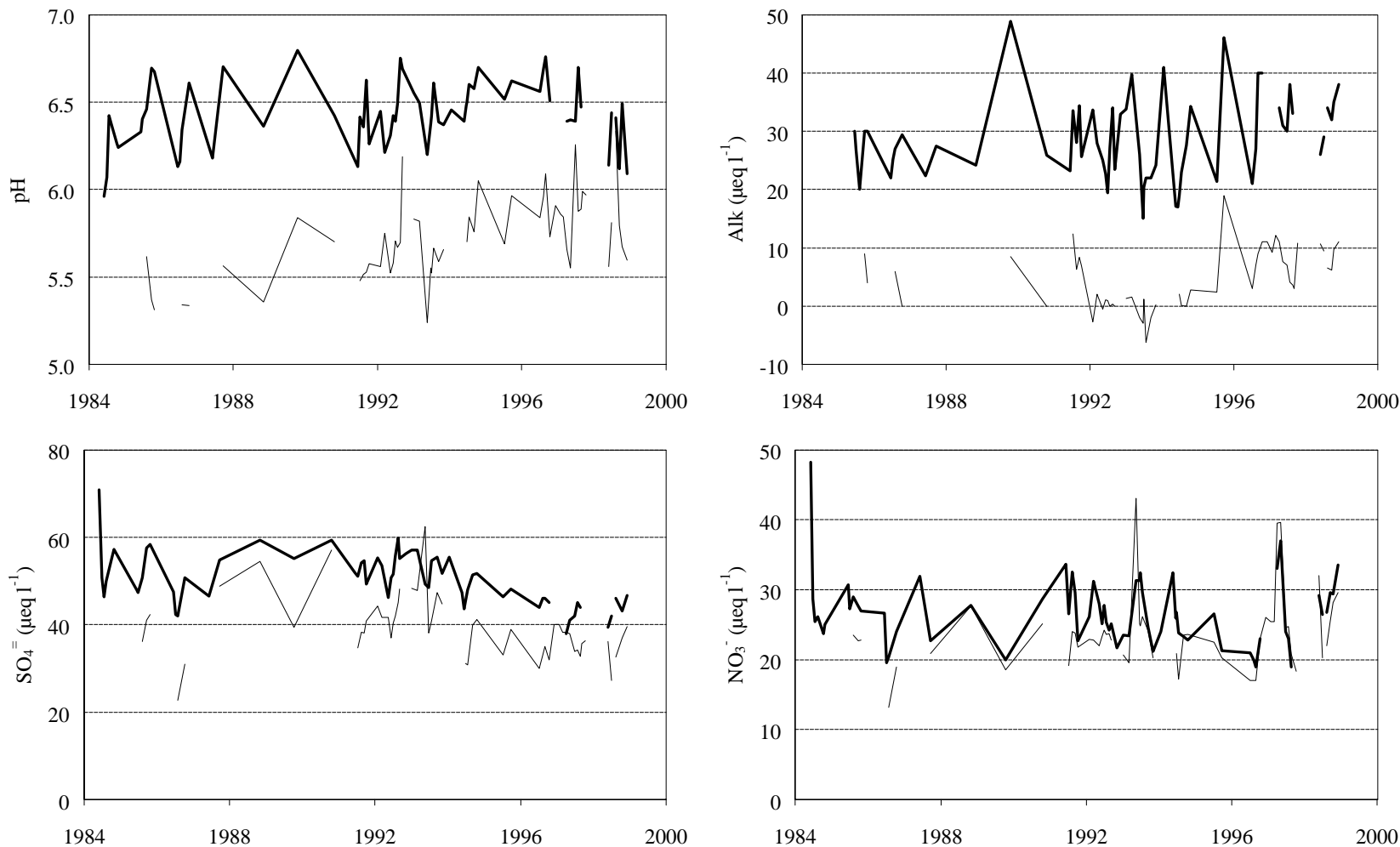

Fig. 4. Trend (1984-98) of $\mathrm{pH}$, alkalinity, $\mathrm{SO}_{4}{ }^{2}$ and $\mathrm{NO}_{3}{ }^{-}$in Lakes Paione Superiore (thin line) and Inferiore (thick line).

sello et al. 1993b; Mosello \& Marchetto 1996). Data collected in six sampling stations in the period 1985-93 showed a steady decrease of concentrations from south to north (Della Lucia et al. 1996). This pattern is clearly correlated with the meteorology of the study area, which receives air masses mainly from the South-East and South-West and so is affected by the fluxes of pollutants coming from the Po Plain, one of the most densely populated and industrialised areas in Italy. This gradient contributes to explaining the different levels of nitrate in rivers, which are markedly lower in the more northerly watershed of the River Cannobino than in those of the rivers Pellino and Pellesino (Boggero et al. 1996).

The most significant long-term trends in atmospheric deposition chemistry are the increase in nitrate and the decrease in sulphate concentrations, which de- 
termine an increase in $\mathrm{pH}$. These trends can be related to changes in atmospheric emissions over the last 20 years from the main sources of pollution: fossil fuel combustion, industrial activities, motor vehicles and agricultural practices. Figure 6 shows the atmospheric anthropogenic emissions of $\mathrm{NO}_{\mathrm{x}}, \mathrm{SO}_{2}$ and $\mathrm{NH}_{3}$ in Italy in the period 1980-1995. There is a clear decreasing trend only in the case of $\mathrm{SO}_{2}$ emission, from $3.7 \times 10^{6} \mathrm{t} \mathrm{y}^{-1}$ to about $1.3 \times 10^{6} \mathrm{t} \mathrm{y}^{-1}$, owing to the reduction in sulphur oxide emission from thermoelectric power plants (which represent $62 \%$ of the total anthropogenic emission) and industrial production $(24 \%) . \mathrm{NH}_{3}$ remained fairly constant (about $0.5 \times 10^{6} \mathrm{t} \mathrm{y}^{-1}$ ), while nitrogen oxides increased slightly from 1986 to 1992 and then decreased in 1993-95. The main sources of $\mathrm{NH}_{3}$ pollution are agriculture and forestry (93\%); the major contribution to $\mathrm{NO}_{\mathrm{x}}$ emission is from motor vehicles $(64 \%)$, followed by thermoelectric plants (20\%) and industry (13\%).
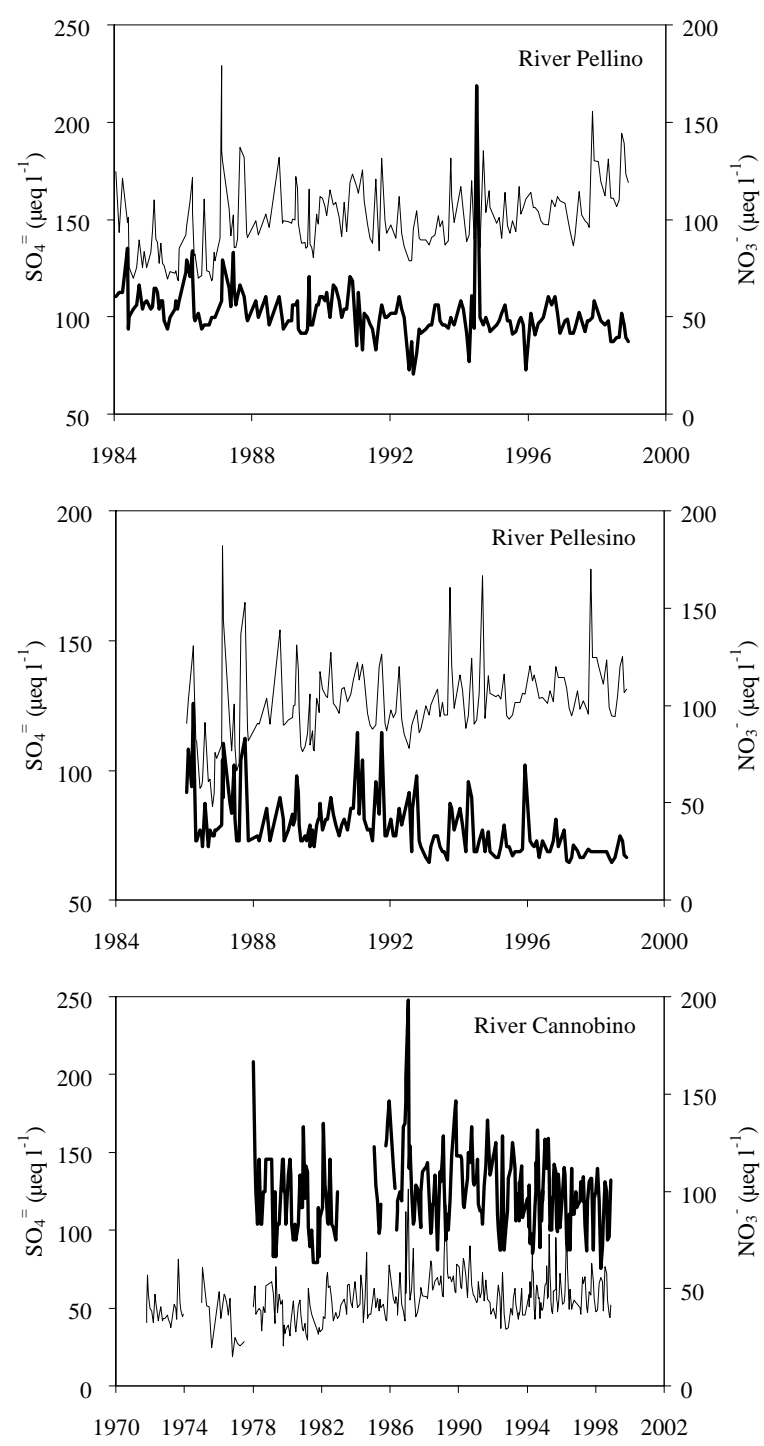

Fig. 5. Trend of $\mathrm{SO}_{4}{ }^{-}$(thick line) and $\mathrm{NO}_{3}{ }^{-}$(thin line) in rivers Pellino, Pellesino and Cannobino.

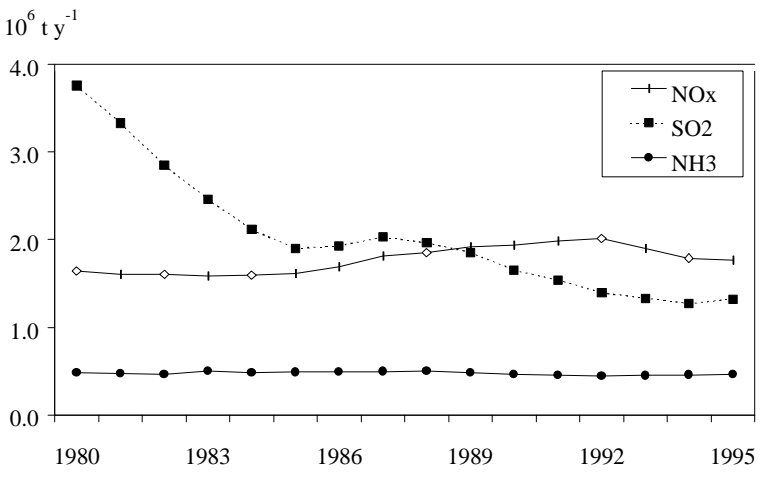

Fig. 6. Trend of atmospheric anthropogenic emissions of $\mathrm{NO}_{\mathrm{x}}$, $\mathrm{SO}_{2}$ and $\mathrm{NH}_{3}$ in Italy for the period 1980-95 (EMEP/CORINAIR 1996).

On the whole, surface water acidification in Italy constitutes only a minor problem. Although the atmospheric deposition of pollutants is quite high in the study area, Italian sites do not seem to be endangered by acid deposition. Compared to the other European ICP sites, $\mathrm{pH}$ and alkalinity in Italian rivers and lakes are rather high, owing to the geo-lithological characteristics of their watersheds which assure the buffer capacity of the waters. The situation is more serious for a number of high altitude lakes in the Alps: the presence of acidic rocks in their catchments, thin or absent soil and scarce vegetation make them more sensitive towards the atmospheric deposition of acidity (Boggero et al. 1993; Marchetto et al. 1995).

The major problem affecting surface water in Italy is the atmospheric deposition of nitrogen compounds. Their atmospheric loads have a strong impact on surface water, forests and ecosystems. Moreover, nitrogen is involved in biological processes to a much greater extent than sulphur.

The decrease in sulphate concentrations observed in almost all the ICP sites in Europe and North America in the 1990's (Lükewille et al. 1997) highlights the importance of nitrate as the second acidifying anion also for the eutrophication of soils and waters. The 1980's were characterised by increases in nitrate content in water in almost all regions. These trends have disappeared in the 1990 's, although there have been no decreases in nitrogen deposition. Probably other regional-scale processes should be taken into account, e.g. climate changes or extreme climatic events. Hydrology also plays an important role on watershed nitrogen cycling and can strongly influence the leaching of nitrate and ammonium from a watershed.

All six Italian sites presented in this paper have proved to be suitable for the Italian participation in the ICP Waters activity. In 1996 they were all included in the new ICP database which contains the chemical and biological data for more than 120 sites in Europe and North America considered in the most recent report (Lükeville et al. 1997). 
In evaluating the effects of acidification on aquatic fauna, the long-term monitoring not only of water chemistry but also of biology is essential. For Italian participation in the programme to be complete, biological data on invertebrates should also be collected and considered, with the aim of assessing their sensitivity towards acidification and to collect information about dose/response relationships.

\section{ACKNOWLEDGMENTS}

This study has been partially supported by a grant from the Italian Ministry of the Environment (cod. 4201/132/98/SIAR).

\section{REFERENCES}

Boggero, A., S. Belfanti, M.C. Brizzio, A. Calderoni \& R. Mosello. 1996. Trends in the chemistry of surface water in north-western Italy. IV. Nitrogen in subalpine rivers Pellino, Pellesino, Pescone and Cannobino (Lago Maggiore watershed). Mem. Ist. ital. Idrobiol., 54: 143-159.

Boggero, A., A. Barbieri, M. Conedera, A. Marchetto, R. Mosello \& G.A. Tartari. 1993. Land cover as a factor influencing the chemistry of mountain lakes in the western Alps. Verh. int. Ver. Limnol., 25: 772-775.

Calderoni, A., R. de Bernardi \& R. Mosello. 1993. Lago d'Orta ecosystem recovery by liming. In: S.E. Jorgensen (Ed.), Guideline Lake Management. ILEC-UNEP, 5: 105144.

Calderoni, A., R. de Bernardi \& R. Mosello. 1994. Recovery of Lago d'Orta by liming. Verh. int. Ver. Limnol., 25: 2016-2020.

Calderoni, A., R. Mosello \& G. Tartari. 1978. Hydrochemistry and chemical budget of Lago di Mergozzo (Northern Italy). Mem. Ist. ital. Idrobiol., 36: 239-266.

de Bernardi, R., A. Calderoni \& R. Mosello. 1996. Environmental problems in Italian lakes Maggiore and Orta as successful examples of correct management leading to restoration. Verh. int. Ver. Limnol., 26: 123-138.

Della Lucia, M., A. Marchetto, R. Mosello \& G.A. Tartari. 1996. Studies on a chemical gradient of atmospheric deposition from the Po Valley to the Alps. Wat. Air Soil Pollut., 87: 171-187.

EMEP/CORINAIR. 1996. Atmospheric emission inventory guidebook. European Environment Agency, February 1996.

Received: June 1999

Accepted: September 1999
Hirsch, R.M., J.R. Slack \& R.A. Smith. 1982. Techniques of trend analysis for monthly water quality analysis. Wat. Resour. Res., 18: 107-121.

Lükewille A., D. Jeffries, M. Johannessen, G. Raddum, J. Stoddard \& T. Traaen. 1997. Transboundary Air Pollution. International Cooperative Programme on Assessment and Monitoring of Acidification of Rivers and Lakes. The nine year report: acidification of surface water in Europe and North America - Long-term developments (1980s and 1990s). NIVA-report $\mathrm{n}^{\circ}$ 3637-97:168 pp.

Marchetto, A., R. Mosello, R. Psenner, A. Barbieri, G. Bendetta, D. Tait \& G.A. Tartari. 1994. Evaluation of the level of acidification and the critical loads for Alpine lakes. Ambio, 23: 150-154.

Marchetto, A., R. Mosello, R. Psenner, G. Bendetta, A. Boggero, D. Tait \& G. A Tartari. 1995. Factors affecting water chemistry of alpine lakes. Aquat. Sci., 57: 81-89.

Mosello, R. \& A. Marchetto. 1996. Chemistry of atmospheric wet deposition in Italy. Results from a five year study. Ambio, 25: 21-25.

Mosello, R., A. Marchetto \& G.A. Tartari. 1988. Bulk and wet atmospheric deposition chemistry at Pallanza (N. Italy). Wat. Air Soil Pollut., 42: 137-151.

Mosello, R., M. Della Lucia, A. Marchetto \& G.A. Tartari. 1993b. Trends in the chemistry of surface water in Northwestern Italy. I. Atmospheric deposition. Mem. Ist. ital. Idrobiol. 51: 147-165.

Mosello, R., M.C. Brizzio, A. Calderoni, A. Marchetto \& G.A. Tartari. 1993c. Trends in the chemistry of surface water in north-western Italy. II. Watershed budget and trends in River Cannobino. Mem. Ist. ital. Idrobiol. 51:167-184.

Mosello, R., A. Marchetto, A. Boggero, M.C. Brizzio, G.A. Tartari \& M. Rogora. 1999. Pluriannual evolution of the hydrochemistry of two alpine lakes (Lake Paione Inferiore and Lake Paione Superiore, Ossola Valley) in relation to atmospheric loads. J. Limnol., 58(1): 43-49.

Mosello, R., A. Barbieri, G. Bendetta, A. Boggero, A. Marchetto, R. Psenner, D. Tait \& G.A. Tartari. 1993a. Quantification of the susceptibility of alpine lakes to acidification. Mem. Ist. ital. Idrobiol., 52: 355-386.

Tartari G.A. \& Mosello R. 1997. Metodologie analitiche e controlli di qualità nel laboratorio chimico dell'Istituto Italiano di Idrobiologia. Documenta Ist. ital. Idrobiol., 60: $160 \mathrm{pp}$. 